\title{
Body Weight Data Collection Date Time
}

National Cancer Institute

\section{Source}

National Cancer Institute. Body Weight Data Collection Date Time. NCI Thesaurus. Code C119781.

The date and time of body weight assessment data collection. 